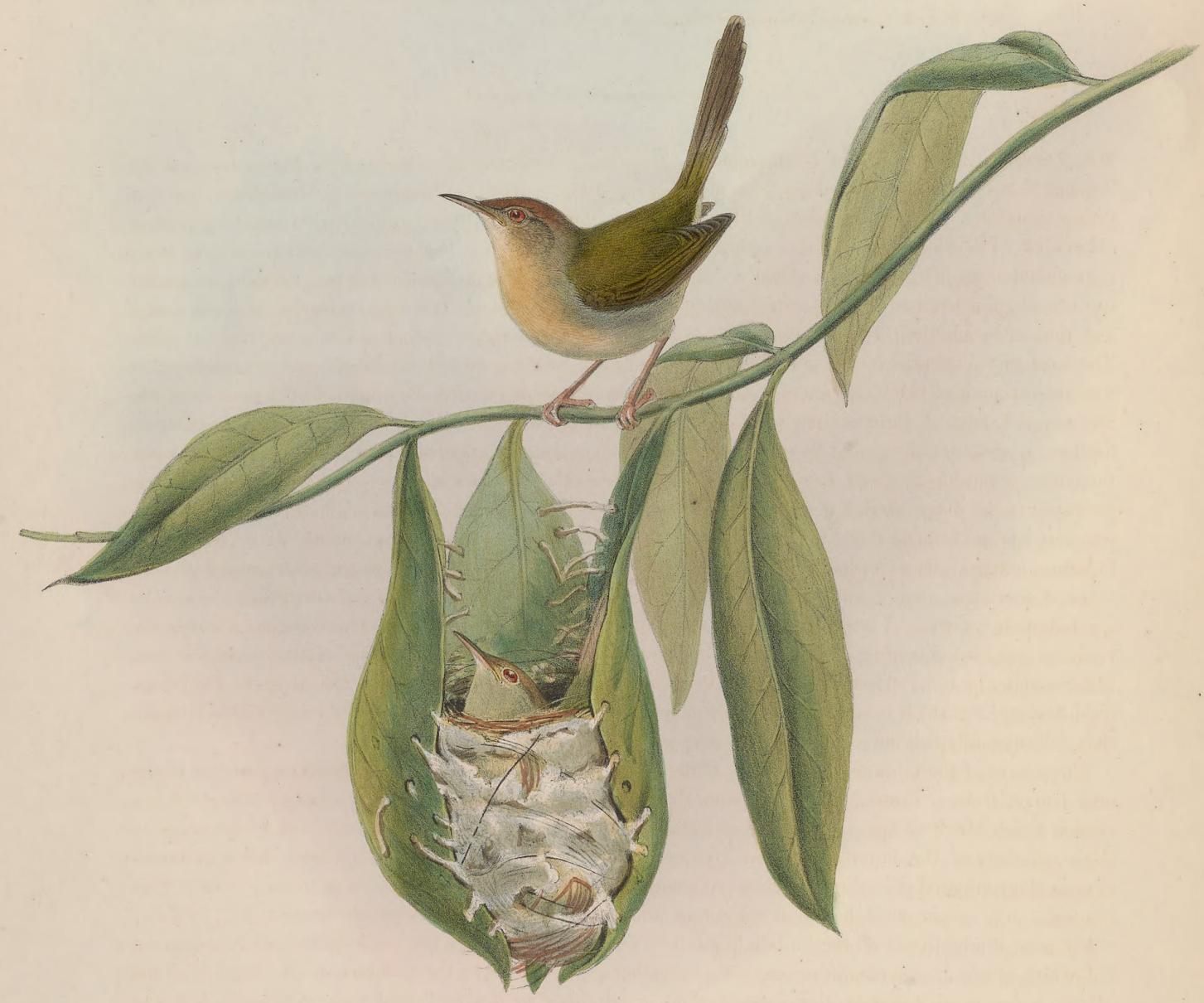

ORTHOTOMUSS LONGICAUDUSS 


\title{
ORTHOTOMUS LONGICAUDUS.
}

\author{
'Tailorbird.
}

Motacilla longicauda, Gmel. edit. Linn. Syst. Nat., tom. i. p. 954.

Orthotomus longicauda, Swinh. Zool., 1858, p. 6229._Idem, Proc. of Zool. Soc., 1871, p. 351.

phyllorrhapheus, Swinh. Ibis, 1860, p. 49 ; 1861, p. 32 ; 1862, p. 258.-Idem, Proc. of Zool. Soc., 1863, p. 294.-Gray, Hand-l. of Birds, part i. p. 195.

Mr. Frederic Moore, in the Monograph of the genus "Orthotomus," submitted to the meeting of the Zoological Society of London on the 28th of February, 1854, and published in their 'Proceedings' for that year, enumerates only nine species of this form, while the late Mr. G. R. Gray, in his recently published 'Hand-list of Birds,' extends the number to thirteen or fourteen. One or other of them has been commented upon by the earliest down to the latest of our ornithological writers on eastern birds, owing to their singular habit of sewing together the leaves of growing plants to form receptacles for their nests, and thus securing their frail structures from falling to the ground or being blown away by the wind. The ingenuity displayed by the "Tailorbirds," as they are called, is so well known to every school-boy that a minute account of it is quite unnecessary, especially as the accompanying illustration will at once enlighten through the sense of sight any one who may be unacquainted with the subject. Whether there are nine or fourteen species, as enumerated by the authors above mentioned, is a question which can only be solved when the entire group has received a more careful investigation than would seem as yet to have been given to it. One species, A. longirostris, has been assigned to New South Wales by Swainson; but I may affirm with certainty that no bird of this form has yet been discovered in that country; neither has the $O$. Hügelii of Pelzeln a better claim to a place in the fauna of New Holland. It is only when numerous examples of both sexes of every species are laid side by side that the specific characters of each are discernible and can be carefully noted down. A question has for some time existed in the minds of ornithologists whether the common species frequenting India and the one so abundantly spread over South China are identical or not. Mr. Swinhoe, in his Revised Catalogue of the Birds of China, published in the "Proceedings of the Zoological Society" for 1871, remarks, "Gmelin's name" [of longicauda] "applies specially to the China bird ; so that its Indian ally will have to take the next in priority of its numerous synonyms."

The figures of the birds on the opposite Plate having been taken from Chinese specimens, and that of the nest copied from a drawing made in China, there can be no doubt of their representing the true $O$. long $i$ caudus, which Mr. Swinhoe states " is an abundant resident from Canton to Foochow ;" and in his notes on the ornithology of the latter district he says "the little Tailorbird cheers up his mate with his well-known note as the contented pair thread their way through the close bents of the long coarse grass "- and further remarks, in a paper read before the Literary and Scientific Society of Amoy, November 17, 1857:"The most diminutive of all the birds is the little Tailorbird (Orthotomus), remarkable for its long pointed bill, which serves as a needle in sewing leaves together round its nest; the underside of a long leaf of the Alpinia nutans is often chosen, the edges of which are drawn together by thread made of spider's web and fibres. The prettiest construction of the kind I have seen was a nest flanked in by three orange-leaves, and placed at the extremity of a bough of an orange-tree. The bird is called Mang-tang-a in the vernacular."

The following is Mr. Swinhoe's description of a male shot at Amoy on the 22nd of February :-

"Forehead ferruginous, gradually changing to olive-brown on the head; back bright olive-green ; wings and tail hair-brown, the coverts margined with olive-green, the primaries with yellowish olive-brown ; round the neck and all the under surface, including the edge of the shoulder, ochreous white, darker on the flanks and buff on the tibiæ; bill pale flesh-colour, dark hair-brown along the culmen; irides buff; a narrow circle round the eye pale yellow; legs and toes pale yellowish brown."

"The two central tail-feathers of the male gradually lengthen until May, when they are about an inch and a half or so longer than the others, which are all somewhat graduated; I observe that these lengthened feathers soon become worn, and usually drop after the first nesting, to be replaced by others only slightly longer than the rest."

The figures and the representation of the nest are all of the natural size. 


\section{$2 \mathrm{BHL}$ Biodiversity Heritage Library}

Gould, John. 1873. "Tailor-bird, Orthotomus longicaudus [PI. 7]." The Birds of Asia 4(XXV), -. https://doi.org/10.5962/p.323417.

View This Item Online: https://www.biodiversitylibrary.org/item/120503

DOI: https://doi.org/10.5962/p.323417

Permalink: https://www.biodiversitylibrary.org/partpdf/323417

\section{Holding Institution}

Smithsonian Libraries

\section{Sponsored by}

Smithsonian Institution Libraries

\section{Copyright \& Reuse}

Copyright Status: Not in copyright

This document was created from content at the Biodiversity Heritage Library, the world's largest open access digital library for biodiversity literature and archives. Visit BHL at https://www.biodiversitylibrary.org. 